\title{
Doctrine of Frustration and Force Majeure Clause: Its Application on Tenancy Contract During the Movement Control Order in Malaysia
}

\author{
MuHAMMAD ASYRAF AZNi \\ SURIA FADHILLAH MD PAUZI \\ IDA ROSNITA ISMAIL
}

\begin{abstract}
The government of Malaysia has declared the Movement Control Order (MCO) for the whole nation in order to flatten the curve of COVID-19 infection. The MCO has, among others, caused parties in a contract to question the effect of the MCO on the contract. As the areas of law are wide, this paper aims to discuss the effect of MCO on a tenancy contract. The paper analysed the legal position of doctrine of frustration and force majeure clause in the context of tenancy contract in Malaysia. The analysis was done based on the law cases and legal provisions in Malaysia. Reference was also made to case law from the United Kingdom and Singapore as their law is in pari materia with Malaysian law and they are persuasive in nature. This paper found that the doctrine of frustration can be invoked if the performance of the obligation under the tenancy contract is prevented due to the MCO. However, the court will apply the doctrine of frustration in a very careful manner to respect the sanctity of the agreement. As for the force majeure clause, it can be successfully invoked if the scope of the clause covers the event in question, such as the MCO. In conclusion, whether a tenancy contract can be terminated due to the MCO, it will depend on the terms of each tenancy contract.
\end{abstract}

Keywords: Contract; COVID-19; force majeure; doctrine of frustration; MCO

\section{INTRODUCTION}

The imposition of the Movement Control Order (MCO) by the Malaysian government and the spreading of COVID-19 pandemic throughout the world has brought about an unprecedented impact on industry and business community. The closure of businesses due to this restriction order has made it difficult for companies to maintain liquidity and revenue because only essential services are allowed to operate. Due to this inactivity, it is common for industries to re-organise the structure of the company, which results in retrenchment and termination of employees. Employees who are laid off suffer loss of income and are unable to perform their obligations in certain aspects such as rent payment. Retail Group Malaysia (RGM) estimates that within the period of the MCO, retail outlets in non-essential business industry incurred an estimated RM14.31 billion in operating costs, which includes rental of premises. ${ }^{1}$ Due to disruption of business and the increase of operating costs, some businesses are unable to perform their contractual obligations. In addition, residential tenancies also face the same problem as many have suffered loss of income and job, and thus, have no means to pay rent. According to a Job Street survey, thirty-five percent of Malaysians have experienced a salary reduction of more than thirty percent during the MCO period and around fifty-four percent of them are actively searching for a job. ${ }^{2}$

The education sector has also felt the impact of the MCO. Due to the MCO, the government has ordered, among others, all universities to close its operation except for essential services. This order, in turn, forces students who have a tenancy contract to go back home and thus leave their rented accommodation unused. It should be noted that a tenancy contract clearly provides for rights and obligations of both landlord and tenant. If either party has defaulted in any of the obligations stipulated under the agreement, legal action can be taken by the aggrieved party. Among the provisions stipulated under the tenancy contract are rental amount, landlord's responsibilities, tenant's obligation, and tenancy period.

Currently there is no statute that governs the scope and delimitation of tenancy contracts; thus, general principles of contract apply. Section $38(1)^{3}$ provides for performance of obligations to be exact and precise unless any law has dispensed with such performance. Thus, the performance of the obligation must be 
performed at the time as agreed by the parties. ${ }^{4}$ Where parties fail either to comply with the terms of the contract, or delay in performing their obligations, or is no longer interested in carrying out their obligations prior to the time agreed, the parties are in breach of contract. Thus, the innocent party is entitled to treat the contract as coming to an end and may be able to recover damages. Moreover, if the defaulting party has received any benefit under the contract, he must restore it back to another party. ${ }^{5}$

In respect of tenancy contract during this uncertain period, some residential tenants are unable to pay rent due to loss of income. For others such as university students, they are ordered to undergo online learning. As a result, many of them have gone back to their hometown and have refused to pay rent since they are not staying at the rented accommodation. On the other hand, for commercial tenants, they must cease their businesses due to the MCO and are unable to generate their revenue from the business premises. The legal issue here is whether the inability to perform their obligations as stated in their tenancy contract, such as payment of rent, due to the global pandemic of COVID-19 and the MCO can be used as a basis to invoke the application of the doctrine of frustration or the force majeure clauses.

\section{PROBLEMS}

There are two problems that this paper seeks to address. Firstly, in what circumstances can the doctrine of frustration be applied in a tenancy contract. Secondly, whether force majeure clause can be invoked due to the MCO.

\section{RESEARCH METHOD}

This paper aims to analyse the application of doctrine of frustration and force majeure clause in the situation when a supervening event strikes beyond the control of contracting parties in respect of their obligations under the tenancy contract. In order to achieve this objective, the researchers started by looking at the Malaysian legal position on this matter. The researchers then analysed the relevant statute and provisions of the law and the relevant case law that discuss termination of contract due to the application of doctrine of frustration or force majeure clause. Reference was also made to case law from other commonwealth jurisdictions such as the United Kingdom (UK) and Singapore in order to achieve the objective of this study. It is because their law is in pari materia with Malaysian law and they are persuasive in nature. This study used doctrinal method in order to investigate the position of law pertaining to the effect of contract in unprecedented situations, which is the MCO due to COVID-19. The primary and secondary data such as legislation, case law, academic articles, and online newspaper articles were coded using the Atlast.ti software focusing on the term "force majeure" and "frustration". The data were then analysed using the content analysis method. This method aims to identify elements that create the legal issue and resolve it through a legal discussion. The materials, among others, were obtained through online databases such as LexisNexis and Current Law Journal.

\section{DISCUSSION}

\section{THE POSITION OF THE LAW ON THE DOCTRINE OF FRUSTRATION}

In Malaysia, Section $57(2)^{6}$ is the provision that provides for the doctrine of frustration. It states that "a contract to do an act which, after the contract is made, becomes impossible, or by reason of some event which the promisor could not prevent, unlawful, becomes void when the act becomes impossible or unlawful." From this provision, Section 57(2) is applicable for situations where the contract becomes impossible "after" a contract has been made. If the contract is impossible to be performed before the contract was made, then it will be governed by Section 57(1). Also, based on Section 57(2) a contract can become impossible to be performed either due to some supervening event or supervening illegality.

To see the application of Section 57(2), the researchers refer to the case of Pacific Forest Industries Sdn Bhd \& Anor $v$ Lin Wen-Chih \& Anor [2019] 6 MLJ 293 at page 3047, where the Federal Court has made a reference to the UK's case of Davis Contractor Ltd v Fareham Urban District Council (1956) AC 696 in which Lord Radcliffe has laid down the test in determining whether a particular contract has been discharged 
by frustration or not. His Lordship held that frustration of contract happens when the contract has become incapable of being performed due to a supervening event, which is not the fault of either party. His Lordship further held that the occurrence of the supervening event has rendered the contract radically different from what the parties has agreed to perform. ${ }^{8}$

Meanwhile, in the case of Ramli bin Zakaria \& Ors. v. Government of Malaysia [1982] 2 MLJ 257 at page $262^{9}$, the Federal Court referred to the House of Lords' decision in the case of Tsakiroglou \& Co Ltd v Noblee Thorl GmbH (1962) AC 93 where Viscount Simonds held that the nature of the contract must be "fundamentally altered" before the doctrine of frustration can be applied in the contract. It means that the very foundation of the contract must be significantly altered. For example, a whole contract will come to an end just because one term of the contract, such as the payment must be made via online banking, becomes impossible to be performed.

In another case, the Court of Appeal in the case of Bandar Subang Sdn Bhd lwn Persatuan Penganut Sri Maha Mariamman Kajang Selangor (pemegang amanah dan pengurusan Kuil Sri Maha Mariamman, Ladang Breamer) [2019] 5 MLJ $732^{10}$ referred to the judgment of Lord Denning MR in the case of Ocean Tankers Corporation v V/O Soyfracht [1964] 1 All ER 161 where, in determining what "a thing radically different from that which was undertaken by the contract" means, His Lordship said this:

To see if the doctrine applies, you have first to construe the contract and see whether the parties have themselves provided for the situation that has arisen. If they have provided for it, the contract must govern. There is no frustration. If they have not provided for it, then you have to compare the new situation with the old situation for which they did provide. Then you must see how different it is. The fact that it has become more onerous or more expensive for one party than he thought, is not sufficient to bring about a frustration. It must be more than merely more onerous or more expensive. It must be positively unjust to hold the parties bound. It is often difficult to draw the line.

Thus, in order to determine whether the supervening event is "a thing radically different from that which was undertaken by the contract", it must be "positively unjust" to hold the parties to the strict performance of the contract.

In the case of Hong Leong Bank Bhd v Tan Siew Nam \& Anor [2014] 5 MLJ 34 at page 53 ${ }^{11}$, the Court of Appeal referred to the statement by Lord Simon in the case of National Carriers Ltd $v$ Panalpina (Northern) Ltd [1981] AC 675 where he stated that a contract is frustrated when a supervening event occurs, which is not the fault of either party of the contract and both parties have not made any provision to cater the happening of the supervening event. ${ }^{12}$ The supervening event must be something that alters the very foundation of the contract, not merely it becomes more expensive or troublesome, where both parties would never expect it to happen at the time of making the contract. As such, it would be unjust to compel them to adhere to the strict compliance of the contract and thus, the parties will be discharged from further performing the contract. ${ }^{13}$ The Court of Appeal also stated that the doctrine of frustration must be applied narrowly because business arrangements should not be simply put to an end just because there is a mere change in situation.

In the case of Edwinton Commercial Corp and another $v$ Tsavliris Russ (Worldwide Salvage and Towage) Ltd (The "Sea Angel") [2007] EWCA Civ $547^{14}$ the UK Court of Appeal refers to the concept of justice introduced by Lord Simon where His Lordship stated that firstly, the doctrine of frustration has been developed by the law in order to help the parties in the contract from having to strictly fulfil their obligations under the contract after a material change in situation takes place. As Lord Sumner said, giving the opinion of a strong Privy Council in Hirji Mulji v Cheong Yue Steamship Co Ltd [1926] AC 497, the doctrine of frustration is really a tool to mitigate the harshness of the rule of strict compliance to the terms of the contract whenever it is proper and just to do so.

Secondly, Lord Wright in the Cricklewood Property and Investment Trust Ltd v Leighton's Investment Trust Ltd [1945] AC 221 held that there is no strict formula for the invocation of doctrine of frustration. Thus, the doctrine of frustration should work in favour of justice whenever there is a fundamental change to the terms of the contract due to a supervening event, which is not the fault of either parties. The Court of Appeal also referred to LJ Bingham statement in the case of The Super Servant Two [1990] 1 Lloyd's Rep 1 where His Lordship said that the objective of having the doctrine of frustration is to give justice whenever the circumstances 
demands for it as asking the parties to adhere to strict compliance of the terms of the contracts after the occurrence of supervening event would result in injustice.

\section{THE POSITION OF THE LAW ON THE FORCE MAJEURE CLAUSE}

In the case of Hong Guan \& Co. Ltd. v R. Jumabhoy \& Sons Ltd. (1960) 26 MLJ $141^{15}$, the Privy Council held that the court must be wary in interpreting the force majeure clause in order to determine the scope of the clause in question.

From this case, it is clear that the application of a force majeure clause will depend on how wide the clause can cover the supervening event in question whereas the doctrine of frustration is wider in scope as it is not limited to the wording of the clause in a contract.

The Singapore Court of Appeal in the case of RDC Concrete Pte Ltd v Sato Kogyo (S) Pte Ltd and Another Appeal [2007] SGCA 39 $39^{16}$ explained principles relating to force majeure clause. The court stated that the aim of having a force majeure provision in a contract is to allow the parties to contractually agree beforehand on what is going to happen to the contract if the events listed under the provision happen. The court highlighted that in determining the application of force majeure clause, the exact construction of the clause is crucial because it would determine the precise scope of the application of the force majeure clause. The court would never imply something which is not intended by the parties of the contract and would respect the principle of freedom of contract by giving full effect to the terms of the force majeure clause made by the parties.

The Singapore Court of Appeal further refers to the work of Prof Treitel on the matter of force majeure clause. Firstly, with the inclusion of force majeure clause, the parties can exclude the application of doctrine of frustration. The effect is that the contract will not come to an end should a supervening event listed under the clause occurs. This is different than the doctrine of frustration where the contact will immediately come to an end once it is frustrated.

Secondly, the parties can provide for relief such as discharge of the contract, or any other reliefs when a supervening event listed under the clause occurs. Without such clause, the supervening events would not have the effect of bringing the contract to an end because the event would not fundamentally alter the foundation of the contract as to discharge the parties from further performance of the contract in accordance to the common law's doctrine of frustration.

Thus, from these statements, it shows that force majeure clause allows the parties to exclude the application of doctrine of frustration or provide for some other reliefs in the occurrence of any supervening event. Force majeure clause also allows the parties to provide for discharge of contract on the occurrence of some specific events, which would fall short under the doctrine of frustration. These are the important features of force majeure clause because it could allow the contract to remain alive (or end it, as the case may be) as compared to the doctrine of frustration that put an end to the contract entirely. In this sense, force majeure clause provides some flexibility to the contracting parties.

The Singapore Court of Appeal also highlighted that the inclusion of force majeure clause in commercial contracts were largely due to the catastrophic effect of the doctrine of frustration, which makes a contract comes to an end. Under the doctrine of frustration, the parties have no other way to keep the contract alive. As such, force majeure clause is being used to mitigate the harshness of the doctrine of frustration and as a tool to design specific clause on how to deal with the risk emerging from a supervening event.

Besides that, doctrine of frustration is difficult to be invoked. Thus, by incorporating the force majeure clause in a contract, the parties can eliminate the uncertainty and difficulties in relying on the common law's doctrine of frustration.

The uncertainty in the application of doctrine of frustration will be eliminated by having a very well-drafted force majeure provision that clearly stipulates the events that fall under the force majeure clause. The hardship that parties would otherwise have to suffer is also minimised in the sense that the force majeure clause can be drafted by providing more commercial-friendly effect when a supervening event listed under the clause occurs. For example, the clause can provide for effects such as the innocent party can provide an extension of time, suspension 
of further obligation, further discussion on how to move forward, or giving one party an option to terminate or continue with the contract. These alternatives are better than having the contract to automatically come to an end.

In terms of interpreting the force majeure clause, the Singapore Court of Appeal referred to the Singapore High Court's decision in Magenta Resources (S) Pte Ltd $v$ China Resources (S) Pte Ltd [1996] 3 SLR 62 at 78, [60] (affirmed in China Resources (S) Pte Ltd $v$ Magenta Resources (S) Pte Ltd [1997] 1 SLR 707). In that case, the court held that the force majeure clause refers to the contractual terms drafted by the parties of the contract in order to deal with a supervening event, which is not the fault of either parties. As such, the court further states that there can be no blanket rule as to say what amounts to a situation of force majeure. Whether a supervening event falls under the force majeure clause will depend on what the parties have contracted and agreed during the execution of the contract. The Singapore Court of Appeal further stated that force majeure clause will be construed strictly.

The Singapore Court of Appeal also held that when a party wants to rely to the application of force majeure clause, the party must bring himself within the scope of the clause and also take all reasonable steps to avoid the application of the clause or mitigate its result. ${ }^{17}$

\section{THE APPLICATION OF DOCTRINE OF FRUSTRATION AND FORCE MAJEURE CLAUSE IN TENANCY CONTRACT}

In order to determine whether a tenancy contract can be terminated due to the MCO, this is where the application of doctrine of frustration can be tested. Based on the position of law highlighted in Section 4.1 of this paper, there are 3 tests to be fulfilled in invoking the doctrine of frustration. Firstly, whether the contract has made a provision for supervening event in question. If the contract has made a provision for the supervening event in question, then contract must be governed by the provision. Therefore, there will be no frustration. However, assuming the tenancy contract does not have provision for the occurrence of supervening event such as the $\mathrm{MCO}$, then the party is allowed by law to invoke the doctrine of frustration.
Secondly, the supervening event relied by the tenant must not be due to himself or his fault. To put it simply, self-induced frustration is not allowed. Since the MCO is enforced by the government, the second test is also likely to be fulfilled.

Thirdly, the supervening event renders the contract radically different from what the parties has agreed to perform. Here is the trickiest part. The tenancy contract is usually drafted in a manner where the landlord would rent the accommodation to a tenant and the tenant agrees to rent the accommodation for the agreed price. That is it. It usually does not go further in specifying the purpose of the rental of such premises. By applying this example to the third test, the landlord can still rent the accommodation to the tenant and the tenant can still rent (and stay) in the accommodation in accordance with the tenancy contract. Since the tenancy contract can be performed without any act, which is "radically different from what has been agreed in the contract", the doctrine of frustration is likely failed to be invoked.

However, the outcome would be different if the tenancy contract is drafted in a more specific manner, for example, it has a term which stated that "the accommodation is rented for the purpose of a tenant's education at the Universiti Kebangsaan Malaysia, Bangi Campus (UKM)." The researchers argue that if the tenancy contract has a term like the example given, then maybe the doctrine of frustration can be successfully invoked. The reason is because the third test in doctrine of frustration requires the supervening event to "fundamentally alter" the contract or make radical change to the term of the contract. Thus, since the MCO had caused UKM to be closed, the contract has been radically changed since the tenant can no longer rent the accommodation for the purpose of his or her study at UKM. It is also positively unjust to hold the parties to the strict performance of the contract when the basic structure of the contract (i.e., the tenancy contract was entered for the purpose of enabling the tenant to study at UKM) has been fundamentally altered. Thus, in order to determine whether the doctrine of frustration can be applied in terminating the tenancy contract, the contract must be examined individually based on what has been agreed by both parties. There can be no 
straightforward answer that will apply to all tenancy contracts.

The next question is whether the tenant can terminate the tenancy contract using the force majeure clause. To answer this question, based on the arguments put forth in Section 4.2 of this paper, it can be said that there are three tests to be fulfilled too. Firstly, there must be a force majeure clause in the tenancy contract. If there is no force majeure clause, then the tenant could not rely on this clause and has to rely on the doctrine of frustration.

Secondly, the tenant who wants to rely on the force majeure clause has a duty to bring himself within the scope of the force majeure clause. Failure to adhere to this duty would fail him in his attempt to invoke the force majeure clause. By using the same example above, the tenant must ensure that the $\mathrm{MCO}$ or the closure of UKM due to the MCO falls within the list of supervening events in the force majeure clause. Based on the researchers' observation, there is unlikely any contract has put the MCO as one of the supervening events in the force majeure clause. Furthermore, it would not be wise for parties to be so specific in putting the term "MCO" as one of the supervening events because the government might use different names in the future, which no one has ever thought of the term before. As such, based on the research, the term like "government intervention" can be used as one of the supervening events that falls within the force majeure clause because the MCO can be argued as a government intervention. That is, it was the government who ordered the enforcement of the MCO and consequently UKM was being ordered to close.

Thirdly, the tenant must show that the occurrence of the supervening event in question must not be of his or her doing or within his or her reasonable control. If this matter goes to court, the court would then determine what the parties have agreed should such supervening event triggers the application of force majeure clause. If the clause provides for the end of the contract and discharges the parties from further obligation, then the court will make such orders. If the clause provides for some other reliefs such as an extension of time or compensation to be paid by a landlord to a tenant, then the court will make such orders. At this juncture, it is worth to note that in invoking the force majeure clause, the rights and obligations of parties are all depending on what they have agreed when contracting. The court will respect the wishes of parties based on the terms of the contract. Similarly, in the case of force majeure clause application, there is no blanket answer to all the tenancy contracts as each agreement will depend on what the contracting parties have agreed into.

\section{CONCLUSION}

COVID-19 pandemic has brought about the unprecedented situation that has never happened before. The government has been enforcing the MCO in its effort to curb and flatten the curve of COVID-19 infection. The MCO, in turn, has caused legal problem, among others, in tenancy contract.

From the above discussion, it can be concluded that the standard tenancy contract would unlikely be able to invoke the application of doctrine of frustration on the ground of an MCO. The result would be different if, for example, the tenancy contract contains a term specifying the purpose of the tenancy contract and that purpose could not be achieved due to the MCO.

As for whether the force majeure clause can be invoked due to an MCO, the tenancy contract with standard force majeure clause would not likely to succeed. The result would also be different if, for example, the force majeure clause contains a term such as "government intervention" as one of its lists of supervening events. Thus, it is crucial to pay attention to terms of the contract in deciding whether or not the tenancy contract can be terminated due to the MCO.

\section{NOTES}

Ganesan, V. How a Malaysian Covid-19 Act Could Help Mall Tenants and Landlords Who Are in Limbo, https:// www.theedgemarkets.com/article/cover-story-malltenants-and-landlords-limbo, 2020.

2 Choong, J. Covid-19: Malaysian Job Losses Could Hit over Two Million, New Survey Finds, https://www. malaymail.com/news/malaysia/2020/06/03/covid-19malaysian-job-losses-could-hit-over-two-million-newsurvey-finds/1871989, 2020.

Section 38(1) of Contracts Act 1950.

$4 \quad$ Lim Yoh v. Astana Strategi (M) Sdn Bhd \& Anor [1998] 3 MLJ 117.

5 Section 65 of Contracts Act 1950. 
$6 \quad$ Section 57(2) of Contracts Act 1950.

7 Forest Industries Sdn Bhd \& Anor v Lin Wen-Chih \& Anor [2019] 6 MLJ 293.

8 Relying on the Doctrine of Frustration During a Pandemic [2020] 1 LNS(A) lxxxiv.

9 Ramli bin Zakaria \& Ors. v. Government of Malaysia [1982] 2 MLJ 257.

10 Bandar Subang Sdn Bhd lwn Persatuan Penganut Sri Maha Mariamman Kajang Selangor (pemegang amanah dan pengurusan Kuil Sir Maha Mariamman, Ladang Breamer) [2019] 5 MLJ 732; Force Majeure in the Age of Covid [2020] 1 LNS(A) xlvi.

$11 \quad$ Hong Leong Bank Bhd v Tan Siew Nam \& Anor [2014] 5 MLJ 34.

12 Lost without a Trace: The employer's Employment Status [2014] 3 ILJ cccxxxv; Termination of Employment for Criminal Misconduct [2016] 2 MLJ ci; Wilson, S. Terminating Contracts, Journal of Building Appraisal 4(3): 225-230, 2009, pg 6.

13 Payment of "Wages for Work Done": A Tale of Two Approaches 1 LNS(A) lxxvi.

14 Edwinton Commercial Corp and another $\mathrm{V}$ Tsavliris Russ (Worldwide Salvage and Towage) Ltd (The "Sea Angel") [2007] EWCA Civ 547.

15 Hong Guan \& Co. Ltd. v R. Jumabhoy \& Sons Ltd. (1960) 26 MLJ 141.

16 RDC Concrete Pte Ltd v Sato Kogyo (S) Pte Ltd and Another Appeal [2007] SGCA 39.

17 The Coronavirus Epidemic: Does It Count as Force Majeure? 1LNS(A) xiii; A Look at Issues Faced by Employers as a Result of the Covid-19 Pandemic and Ensuing Movement Control Order 1 LNS(A) lxxxv.

\section{REFERENCES}

A Look at Issues Faced by Employers as a Result of the Covid-19 Pandemic and Ensuing Movement Control Order 1 LNS(A) lxxxv.

Bandar Subang Sdn Bhd lwn Persatuan Penganut Sri Maha Mariamman Kajang Selangor (pemegang amanah dan pengurusan Kuil Sir Maha Mariamman, Ladang Breamer) [2019] 5 MLJ 732.

Contracts Act 1950.

Chin, C. W. W. \& Ning, S. Z. 2020. The coronavirus epidemic: Does it count as force majeure? 1 (LNS(A) xiii).

Choong, J. 2020. Covid-19: Malaysian job losses could hit over two million, new survey finds. https:// www.malaymail.com/news/malaysia/2020/06/03/ covid-19-malaysian-job-losses-could-hit-over-twomillion-new-survey-finds/1871989. Accessed on: 20 August 2020.

Eastacres Development Sdn Bhd v Fatimah Bt. Mutallip \& Anor [2000] MLJU 46

Edwinton Commercial Corp and another $\mathrm{v}$ Tsavliris Russ (Worldwide Salvage and Towage) Ltd (The "Sea Angel") [2007] EWCA Civ 547.

Forest Industries Sdn Bhd \& Anor v Lin Wen-Chih \& Anor [2019] 6 MLJ 293.
Ganesan, V. 2020. How a Malaysian Covid-19 Act Could Help Mall Tenants and Landlords Who Are in Limbo https://www.theedgemarkets.com/article/ cover-story-mall-tenants-and-landlords-limbo [diakses pada 20 August 2020].

Hong Guan \& Co. Ltd. v R. Jumabhoy \& Sons Ltd. (1960) 26 MLJ 141

Hong Leong Bank Bhd $\mathrm{v}$ Tan Siew Nam \& Anor [2014] 5 MLJ 34.

Lim Yoh v. Astana Strategi (M) Sdn Bhd \& Anor [1998] 3 MLJ 117.

Lost without a Trace: The employer's Employment Status [2014] 3 ILJ cccxxxv.

Mark, J. 2020. Payment of "Wages for Work Done": A Tale of Two Approaches. 1 (LNS(A) lxxvi).

Mohamed, A. a. A. 2014. Lost without a Trace: The Employee's Employment Status. 3 cccxxxv.

Mohamed, A. a. A. 2016. Termination of employment for criminal misconduct 2(MLJ ci).

Muhammad, A. 2020. Relying on the doctrine of frustration during a pandemic. 1 (LNS(A) lxxxiv).

Netto, A. A. 2020. Force majeure in the age of covid. 1 (LNS(A) xlvi).

Payment of "Wages for Work Done": A tale of two approaches 1 LNS(A) lxxvi.

Ramli bin Zakaria \& Ors. v. Government of Malaysia [1982] 2 MLJ 257.

Relying on the Doctrine of Frustration During a Pandemic [2020] 1 LNS(A) lxxxiv.

RDC Concrete Pte Ltd v Sato Kogyo (S) Pte Ltd and Another Appeal [2007] SGCA 39.

Seadrill Ghana Operations Ltd v Tullow Ghana Ltd [2019] 1 All ER (Comm) 34.

Termination of Employment for Criminal Misconduct [2016] 2 MLJ ci.

The Coronavirus Epidemic: Does It Count as Force Majeure? 1LNS(A) xiii.

Wilson, S. 2009. Terminating contracts. Journal of Building Appraisal 4(3): 225-230.

Muhammad Asyraf Azni

Faculty of Law

Universiti Kebangsaan Malaysia

43600 Bangi, Selangor.

Email: asyrafazni@gmail.com

Suria Fadhillah Md Pauzi

Faculty of Law

Universiti Teknologi MARA,

Cawangan Pahang, Kampus Raub

27600 Raub, Pahang.

Email: suriapauzi@uitm.edu.my

Ida Rosnita Ismail

UKM-Graduate School of Business

Universiti Kebangsaan Malaysia

43600 Bangi, Selangor

Email: idarosnita@ukm.edu.my 